\title{
Does land use type impact the demographic and spatial structures of Adansonia digitata $L$. in the Pendjari Biosphere Reserve in Northern Benin?
}

\author{
Orgely Doris Imeilda Assog BA ${ }^{1,2}$ \\ Kolawolé Valère SALAKO ${ }^{2}$ \\ Benjamin FANTODJI ${ }^{2}$ \\ Éméline P. S. AssÉdÉ ${ }^{3}$ \\ Achille Ephrem Assog BADJO ${ }^{2,4}$ \\ Paxie Wanangwa CHIRWA ${ }^{1}$ \\ ${ }^{1}$ University of Pretoria, \\ Department of Plant \& Soil Sciences, \\ Plant Sciences Complex \\ Hatfield, Pretoria 0028 \\ South Africa \\ ${ }^{2}$ University of Abomey-Calavi \\ Faculté des Sciences Agronomiques \\ Laboratoire de Biomathématiques \\ et d'Estimations Forestières \\ 04 BP 1525, Cotonou \\ Benin \\ ${ }^{3}$ University of Parakou \\ Faculty of Agronomy \\ 03 BP 123, Parakou \\ Benin \\ ${ }^{4}$ University of Abomey-Calavi \\ Laboratory of Applied Ecology \\ 01 BP 526, Cotonou \\ Benin

\section{Auteur correspondant / \\ Corresponding author:} \\ Orgely Doris Imeilda Assogba - \\ doris1assogba@gmail.com - \\ ORCID ID:0000-0002-2908-2666
}

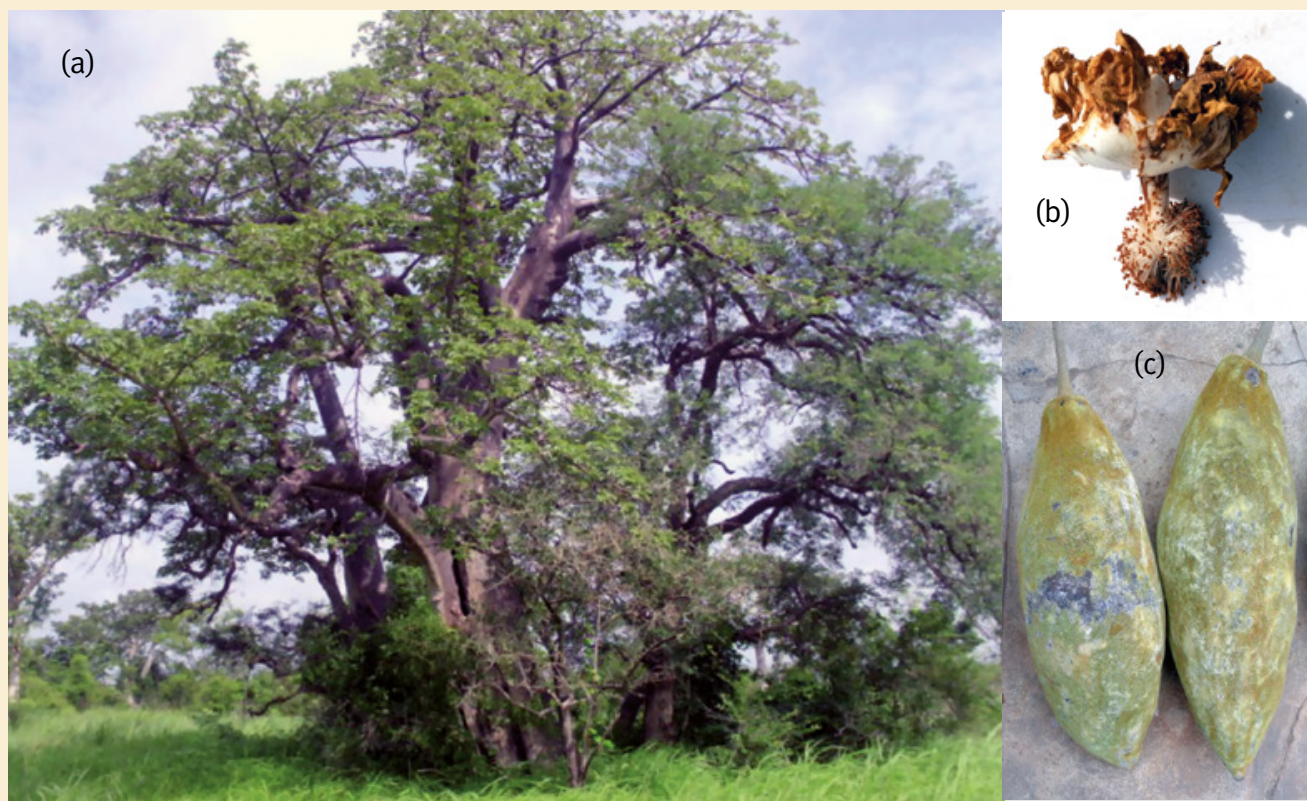

Photo 1.

A baobab tree (a), Adansonia digitata, the flowers (b), and the fruits (c). Photos O. D. I. Assogba, 2019.

Doi : 10.19182/bft2020.344.a31908 - Droit d'auteur (c) 2020, Bois et Forêts des Tropiques @ Cirad - Date de soumission : 23 septembre 2019 ; date d'acceptation : 13 avril 2020 ; date de publication : $1^{\text {er }}$ juin 2020.

\section{cirad}

Licence Creative Commons :

Attribution 4.0 International (CC BY 4.0).
Citer l'article / To cite the article

Assogba O. D. I., Salako K. V., Fantodji B., Assédé E. P. S., Assogbadjo A. E., Chirwa P. W., 2020. Does land use type impact the demographic and spatial structures of Adansonia digitata L. in the Pendjari Biosphere Reserve in Northern Benin? Bois et Forêts des Tropiques, 344 : 59-72. Doi: https://doi.org/10.19182/bft2020.344.a31908 


\section{RÉSUMÉ}

\section{Le type d'utilisation des terres impacte- t-il les structures démographiques et spatiales des populations de Adanso- nia digitata $\mathrm{L}$. dans la réserve de la bios- phère du Pendjari au nord du Bénin ?}

Les modifications des types d'occupation des sols sont un facteur majeur de perte de diversité biologique et de déclin des espèces. Les réponses à ces modifications sont spécifiques aux espèces, et peuvent être dépendantes du contexte. La connaissance de ces réponses est indispensable à la gestion des essences d'arbres sauvages ayant une importance socio-économique. Le baobab, Adansonia digitata L., est une essence largement utilisée en agroforesterie traditionnelle en Afrique subsaharienne. Cette étude évalue l'impact des modifications du type d'occupation des sols sur la structure populationnelle et spatiale des peuplements de baobabs. En se basant sur les données d'inventaire et la cartographie des baobabs présents sur 12 placettes de $250 \mathrm{~m} \times 250 \mathrm{~m}$, l'étude compare la densité et la hauteur totale des arbres, leur distribution selon leur diamètre, la stabilité des peuplements et leurs relations spatiales au sein d'une aire strictement protégée (parc national), d'une zone tampon et de terres agricoles (Matéri et Boukombé) dans la Réserve de la biosphère du Pendjari au Bénin. Les résultats montrent que les plus fortes densités d'arbres jeunes et matures se situent dans les terres agricoles (de Matéri, en particulier), ensuite dans la zone tampon et le parc national. Aucun écart significatif entre les hauteurs totales et les diamètres des arbres n'est constaté pour les différents types d'occupation des sols. La distribution selon le diamètre présente une forme en " I » inversé, la pente négative et les mesures de stabilité populationnelle affichant des valeurs plus favorables (pour Matéri en particulier), mais la pente est aplatie pour la zone tampon. Les distributions spatiales des baobabs juvéniles et adultes sont aléatoires et indépendantes les unes des autres. La distribution spatiale des baobabs adultes et juvéniles est également indépendante de celle des autres essences, quel que soit le type d'occupation des sols. L'étude en conclut que la conservation des baobabs est meilleure dans les zones agricoles que dans le parc national, mais que la différence entre le parc et les zones agricoles semble dépendre du contexte et serait liée aux conditions environnementales locales, au contexte socio-écologique et aux interactions avec les baobabs.

Mots-clés : terres agricoles, structure populationnelle, aire protégée, recrutement, distribution spatiale, Bénin.

\section{ABSTRACT}

\section{Does land use type impact the demogra- phic and spatial structures of Adansonia digitata L. in the Pendjari Biosphere Reserve in Northern Benin?}

Changes in land use type (LUT) are a major driver of biodiversity loss and species decline. Responses to changes in LUT are species-specific, which may in turn be context-dependent. Understanding such responses is essential for the management of socio-economically important wild tree species. The baobab, Adansonia digitata L., is an important traditional agroforestry tree species in Sub-Saharan Africa. This study assesses how LUT affects the demographic and spatial structures of baobab stands. Using data from a census and mapping of baobab trees in 12 plots of $250 \mathrm{~m} \times 250 \mathrm{~m}$ each, the study compared baobab tree density, total height and diameter, diameter size-class distribution (SCD), stand stability, and spatial relationships in a strictly protected area (national park), a buffer zone and farmlands (Matéri and Boukombé) in the Pendjari Biosphere Reserve in Benin. The results show that the highest young and adult tree densities are in farmlands (particularly in Matéri), followed by the buffer zone and the national park. No significant differences in tree diameter and total height of baobab trees were found among the different LUT. The SCD had a reverse J-shape with a better negative slope and population stability metrics in farmlands (particularly in Matéri) but a flattened slope in the buffer zone. The spatial distributions of juvenile and adult baobab trees were random, and independent of each other. The spatial distribution of juvenile and adult baobabs was also independent of the other tree species, irrespective of LUT. It was concluded that baobab conservation is better in farmlands than in the national park but that the difference between park and farmlands may be context-dependent, probably linked to local environmental conditions, the socio-ecological context and interactions with baobab trees.

Keywords: farmland, population structure, protected area, recruitment, spatial distribution, Benin.

\section{Impacto del tipo de utilización de las tierras en las estructuras demográfica y espacial de Adansonia digitata $\mathrm{L}$. en la reserva de la biosfera Pendjari del norte de Benín}

Los cambios en el tipo de utilización de las tierras (LUT) son un importante impulsor de la pérdida de biodiversidad y de la disminución de las especies. Las respuestas a los cambios en el LUT son específicas de las especies, y pueden depender del contexto. Comprender estas respuestas es esencial para la gestión de las especies de árboles silvestres importantes socioeconómicamente. El baobab, Adansonia digitata L., es una especie de árbol importante en la agrosilvicultura tradicional del África subsahariana. Este estudio evalúa cómo el LUT afecta a la estructura demográfica y espacial de la masa forestal de baobabs. Utilizando los datos de un censo y la cartografía de árboles de baobab de 12 parcelas de $250 \mathrm{~m} \times 250 \mathrm{~m}$ cada una, el estudio comparó la densidad de árboles de baobab, la altura y el diámetro totales, la distribución por tamaño diametral (SCD), la estabilidad de la masa y las relaciones espaciales en un área estrictamente protegida (parque nacional), una zona tampón y dos terrenos agrícolas (Matéri y Boukombé) en la reserva de la biosfera Pendjari, de Benín. Los resultados mostraron que las densidades más elevadas de árboles jóvenes y adultos se encuentran en las tierras agrícolas (especialmente en Matéri), seguidas por la zona tampón y el parque nacional. No se encontraron diferencias significativas en el diámetro y la altura total de los árboles de baobab entre las diferentes LUT. La SCD tenía una distribución en J invertida con una mejor pendiente negativa y métrica de estabilidad de población en las tierras agrícolas (especialmente en Matéri), aunque con una pendiente aplanada en la zona tampón. Las distribuciones espaciales de baobabs jóvenes y adultos eran aleatorias, e independientes unas de otras. Las distribuciones espaciales de baobabs jóvenes y adultos también eran independientes de las otras especies de árboles, para cualquier LUT. Se concluyó que la conservación del baobab es mejor en las tierras agrícolas que en el parque nacional, pero que la diferencia entre el parque y las tierras agrícolas puede depender del contexto, probablemente esté relacionada con las condiciones medioambientales locales, el contexto socioecológico y las interacciones de los árboles de baobab.

Palabras clave: tierras agrícolas, estructura de la población, zona protegida, repoblación, distribución espacial, Benín. 


\section{Introduction}

The African baobab, Adansonia digitata L. is an important tree species (photo 1 ) and is crucial in sustaining rural livelihood through the supply of non-woody resources. Humans use most parts of the tree species (Sidibe and Williams, 2002). It can, for example, be used as a supplement in the local diets, as herbal treatment and as a safety-net during crop failure (Assogbadjo et al., 2005). Other products from the baobab include cooking oil, cosmetics for both domestic and international markets (Munthali et al., 2013). Locally, baobab pulp is also processed into various juices while internationally, pulp powder is exported to Europe. In Zimbabwe, it has been reported that baobab fruit enhanced revenue generation of people in local regions by $250 \%$ (Gruenwald and Galizia, 2005).

The main habitat of the African baobab is the savannah ecosystem, which has been affected by human activity (Lykke, 1998), possibly including the population structure of this valuable tree species. Tree harvesting, land clearing for agriculture and grazing have negatively impacted the composition of species and also its distribution and population status (Houéhanou et al., 2013). McNeely (1997) has mentioned that at the regional level, the extinction of the plant species is about $76 \%$ owing to the various disturbances of the habitats. Adomou et al. (2010) found that in Benin, $10 \%$ of the flora (i.e. 280 species of plants) is threatened and is listed on the IUCN Red List. One of the primary goals in setting protected areas, including national parks and biosphere reserves, is to offer safe place for the conservation of a viable sample of the biodiversity, especially species that may be endangered by anthropogenic activities (e.g. overexploitation, improper land use, etc.). Several studies have been dedicated to the understanding of the extent to which protected areas are effective in conserving biodiversity, particularly threatened species or overexploited useful plant species. Most of these studies have compared the population structure and stability of the focused species across different land use types (e.g. Dhillion and Gustad, 2004 ; Djossa et al., 2008; Schumann et al., 2010). Usually, the population structure is assessed in terms of tree density, growth parameters (stem diameter, and height, etc.), natural regeneration, and diameter size-class distribution. Existing data suggests that $60 \%$ of endangered plant species are represented in protected areas (Vellak et al., 2009). There is evidence that land-use type has an impact on the population structure and stability of important plants, including baobab case studies (e.g. Dhillion and Gustad, 2004; Djossa et al., 2008; Schumann et al., 2010). However, support to whether the species are well conserved in protected areas is mixed. Schumann et al. (2010) reported in Burkina Faso a higher number of baobab trees in the W National Park and villages than in croplands and fallows. The authors also found a good regeneration in the park but rather a lack of recruit- ment in non-protected sites (e.g. fallows, croplands and villages stand). However, other studies in Mali showed that baobab density and good regeneration are rather linked to human activities, especially in crop lands and villages (Dhillion and Gustad, 2004; Duvall, 2007). The authors attributed this to management practices related to the land use type which may be positive (e.g. seedling protection and/or transplanting and unintentional dispersal of seeds in garbage) or detrimental (e.g. livestock browsing). Duvall (2007) even suggests that human settlement leads to the development of baobab groves at settlement sites and postulates that baobabs might have been introduced centuries ago. These findings show that the impacts of land use type are clearly unpredictable even for the same species, and that this may be context dependent. In addition, interesting information on population status can be gained from the analysis of spatial arrangement of a tree in relation to its conspecific and heterospecific individuals, especially in terms of the interaction and spacing (Salako et al., 2019). Spatial pattern concerns the past, present and the future conditions of a species (Law et al., 2009). Spatial pattern analysis has been used to gain information on tree spacing for many non-timber products providing tree species, for example Sclerocarya birrea (A. Rich.) Hochst. (Abdourhamane et al., 2017), and Borassus aethiopum Mart. (Salako et al., 2019), and baobab tree association with human settlements (Duvall, 2007).

In many west-African countries, including in Benin, baobab trees are found within and outside protected areas. Baobab may exhibit differences in population status because of various anthropogenic disturbances and environmental conditions occurring in each specific habitat (Schumann et al., 2010). In the Biosphere Reserve of Pendjari, one of the largest and renowned reserves in West-Africa, baobab stands are found in the Pendjari National Park (strictly protected area), in the buffer zone which is a partially protected zone where human activities are implemented but with some restrictions, and in the surrounding farmlands where human activities are not controlled and local people intensively interact with baobab (Assogbadjo et al., 2005). These baobab trees provide vital resources for local people. Therefore, decline of baobab from these areas constitutes a serious threat to their livelihoods. The reserve also offers an ideal system to examine how effective a strictly protected area conserves this useful species.

Therefore, the study objective was to assess the impact of different land use types (farmlands, buffer zone, and national park) on the demographic and spatial structures of baobab in the Pendjari Biosphere Reserve. Specifically, the study compared (1) the demographic structure and, (2) the intraspecific and interspecific spatial patterns of baobab in the three different land use types (LUT). 


\section{Legend}

Water line

Boundaries of Atacora

Water area

Pendjari

Study areas
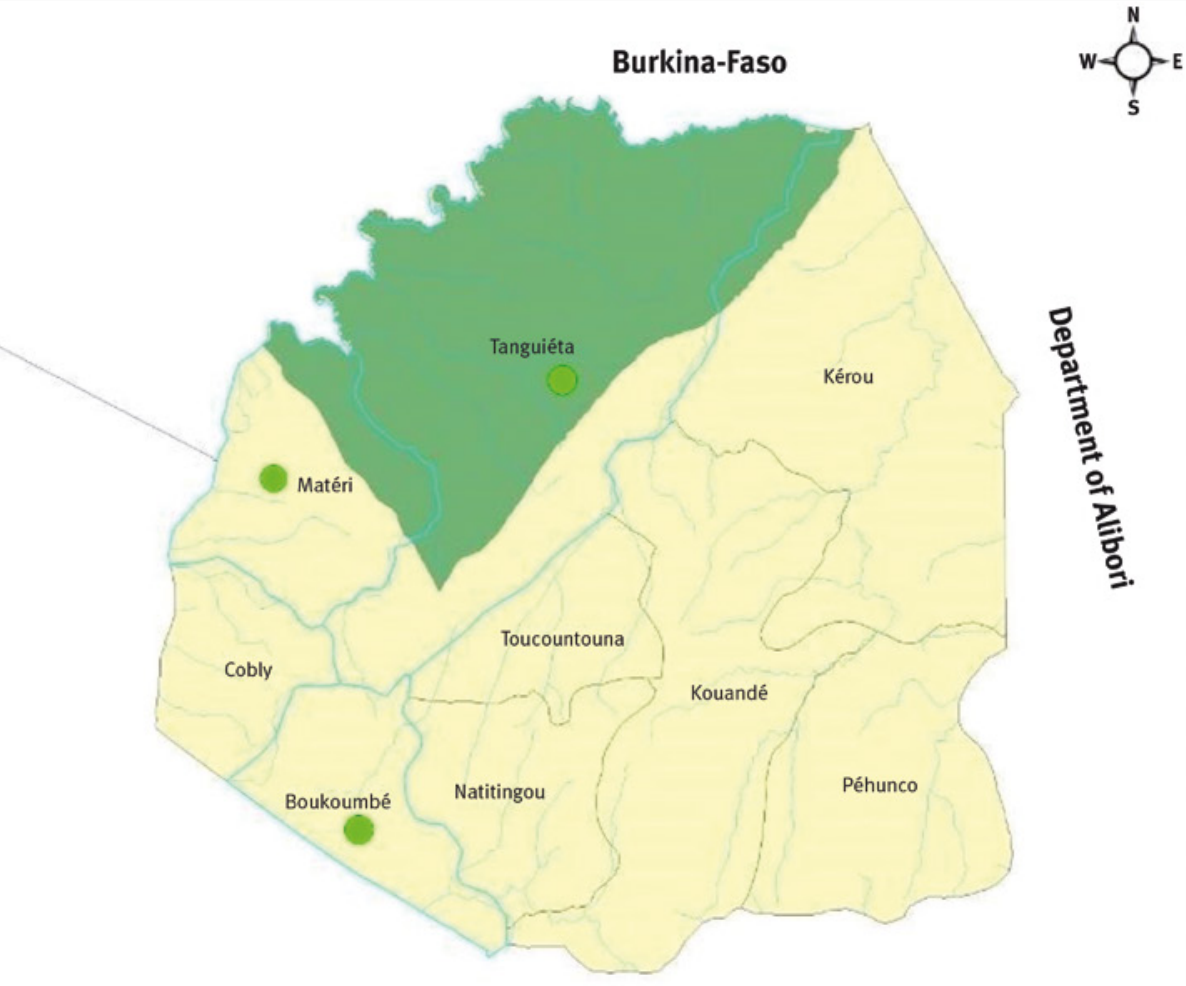

Figure 1.

Study areas showing the Pendjari Biosphere and localities.

\section{Methods}

\section{Study area}

The study was conducted in the northern part of Benin especially in the Biosphere reserve of Pendjari (BRP) and its surrounding farmlands (Matéri and Boukombé) (figure 1). The BRP is between $9^{\circ} 45^{\prime} \mathrm{N}$ and $12^{\circ} 25^{\prime} \mathrm{N}$ and is in the semiarid region. The native vegetation consists of savannahs, shrubs, and trees. The unimodal regime of the annual rainfall of this area is from May to November and varies from 900 to $1,000 \mathrm{~mm}$ and the mean temperature is between 24 and $31^{\circ} \mathrm{C}$. This zone has well drained lithosols, well drained and hydromorphic soils (Gnanglè et al., 2011). In Benin, baobab tree species occur throughout the country at different densities depending on climatic region. The mean population density was estimated as five baobab trees per $\mathrm{km}^{2}$ and the semi-arid region, especially the North-Western part is one of the hotspots of baobab in the country (Assogbadjo et al., 2005).

\section{Sampling and data collection}

Data collection was done from July to August 2017 in the National Park, buffer zones where human activities are restricted and controlled, and farmlands (Matéri and Boukombé) where land is used for agriculture. Matéri and Boukombé were considered because they were previously reported as baobab hotspots where baobab trees can be found both on farmlands and in homesteads (Assogbadjo et al., 2005).

Three sample plots of $250 \mathrm{~m}$ x $250 \mathrm{~m}$ (6.25 ha) were randomly demarcated at each site with a total of 12 plots (75 ha). This plot size was chosen in order to have enough individuals for spatial ana-

Figure 2.

Mapping the process of trees in the plot of $250 \mathrm{~m} \times 250 \mathrm{~m}$.

R1, R2, R3 are the reference points for tree mapping. 
lysis (Salako et al., 2019). The geographical position of the individual plot was registered with the Global Positioning System (GPSMAP Garmin 62st, accuracy $3 \mathrm{~m}$ ). The individual plot was split in 5 strips $(50 \mathrm{~m} \times 250 \mathrm{~m}$ ) to facilitate the data collection and to avoid repetitions and omissions in referencing baobab individuals (figure 2). All baobab individuals irrespective of their size and other trees with diameter at breast height ( $\mathrm{dbh}$ ) greater than or equal to $5 \mathrm{~cm}$ were noted. Starting with the first reference (R1), the process to map the trees was to link an individual tree to one of its neighbours by distance (with tape), slope and azimuth (with Clinometer) (Salako et al., 2019). For each individual, tree girth (later changed into stem dbh) and tree total height were recorded. Baobab seedlings and saplings (tree with $\mathrm{dbh}<5 \mathrm{~cm}$ ) were also totaled in the compartments.

\section{Data and statistical analyses}

\section{Demographic structure and stability across LUT}

The demographic structure was assessed using tree density, average tree growth trait (diameter and total height) (table I), and tree height and diameter size-class distribution (SCD). Average density, diameter, and height of young trees $(0<\mathrm{dbh}<50 \mathrm{~cm})$ and adult tree $(\mathrm{dbh}>50 \mathrm{~cm})$ were computed. One-way analysis of variance and Fisher's LSD test were used to compare LUT.

To assess tree SCD, trees were grouped into eight size-classes, based on diameter (i.e. 0-49 cm, 50-99 cm, 100-149 cm, 150-199 cm, 200-249 cm, 250-299 cm, 300$349 \mathrm{~cm}$, and greater than or equal to $350 \mathrm{~cm}$ ) and in seven size-classes based on total height (i.e. 0-2.99 m, 3-5.99 m, 6-8.99 m, 9-11.99 m, 12-14.99 m, 15-17.99 m, 18-20.99 m height). Stem numbers were counted per class. Least squares regression was computed on the distribution data showing the evolution of the tree density (response variable) as a function of the centres of dbh classes on a log scale. The SCD slope obtained from the analysis was used as an indicator of the demographic structure (Martins and Shackleton, 2017). A positive slope denotes poor recruitment with fewer densities of stems in the smaller classes and higher in the larger sized classes, implying a stand with a unimodal size-class curve. Negative slopes indicate the inverse J- shaped sizeclass distribution curve with best recruitment, i.e. higher densities stem in smaller sized classes and low densities in bigger sized classes. A flatted slope denotes an identical number of the stem in smaller and larger sized classes indicating populations with flat SCD curves (Obiri et al., 2002).

The stability of the population was measured using three parameters: the permutation index $(P)$, the Simpson's dominance index (S) and the quotient (Q) within consecutive sized classes (Shen et al., 2013) (see formula details in table I). Simpson's dominance index evaluates the uniformity of the size-class of trees (Martins and Shackleton, 2017). This denotes evenness in the SCD irrespective of rank (Martins and Shackleton, 2017). According to Botha et al. (2002), the standards state that when the Simpson index is less than 0.1 , it is a uniform distribution in diameter sizeclasses, whereas when it is greater than 0.1 , it is a stable population and size-classes are higher. Many authors, like Venter and Witkowski (2013) and Martins and Shackleton (2017), have used the permutation's index which was formulated by Wiegand et al. (2000). It determines the level of deviation from the monotonic reduction predicted in an undisturbed stand. To calculate the permutation index $(P)$, diameter size-classes were arranged in increasing order and compared to the ranking of their actual frequency. A value of the permutation index approaching zero indicates an undisturbed population, and the higher the permutation index the more disturbed is the population (Helm and Witkowski, 2012). Quotients between consecutive size-classes were presented graphically and the shape of fluctuations was analysed. Fluctuating quotients between consecutive size-classes denote unstable stands and constant quotients imply a stable stand.

Table I.

Description of the demographic structure and stability parameters.

\section{№ Parameters}

1 Tree densities of the populations

\section{Formula}

$$
N=\frac{\mathrm{n}}{\mathrm{S}}
$$

2 Average diameter of the stem $\left(D_{g}\right.$ in $\left.\mathrm{cm}\right)$

$$
D_{g}=\sqrt{\frac{1}{n} \sum_{i=1}^{n} d_{i}^{2}}
$$

3 Tree height

$$
H=\frac{1}{n} \sum_{i=1}^{n} h_{i}
$$

4 Simpson index of dominance (Sp)

$$
S=\frac{1}{n(n-1)} \sum_{i=1}^{12} n_{i}\left(n_{i}-1\right)
$$

5 Permutation index (P)

$$
P=\sum_{i=1}^{12}\left|j_{i}-i\right| j_{i}(i=1 \text { to12) }
$$

6 Quotients between successive size-classes
$\mathrm{Q}=\mathrm{n}_{\mathrm{i}-\mathrm{j}} / \mathrm{n}_{\mathrm{i}}$

\section{Definition}

$\mathrm{N}$ : mean number of the stem in each plot (stems/ha) (Philip, 1994)

$\mathrm{n}$ : total of the stem in the plot

s: unit area of the plot

Quadratic mean of diameter trees in the stand

$\mathrm{d}_{\mathrm{i}}$ : diameter of $\mathrm{i}^{\text {th }}$ tree

Arithmetic mean of tree height

A measure of a size-class dominance, with $n$ total of tree and $n_{i}$ the number of the tree in class $i$

$\mathrm{J}_{i}$ rank of sized classes $\mathrm{i}(\mathrm{i}=1$ for small stems), and the first rank $\left(O_{i}=1\right)$ attributed to the mostly frequent sized class

$\mathrm{n}_{\mathrm{i}}$ : number of individuals in class $\mathrm{i}$

$n_{\mathrm{i}-1}$ : number of individuals in preceding class

\section{References}

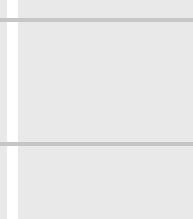

(Wiegand et al., 2000; Botha et al., 2002)

\section{. \\ (1)

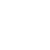

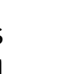




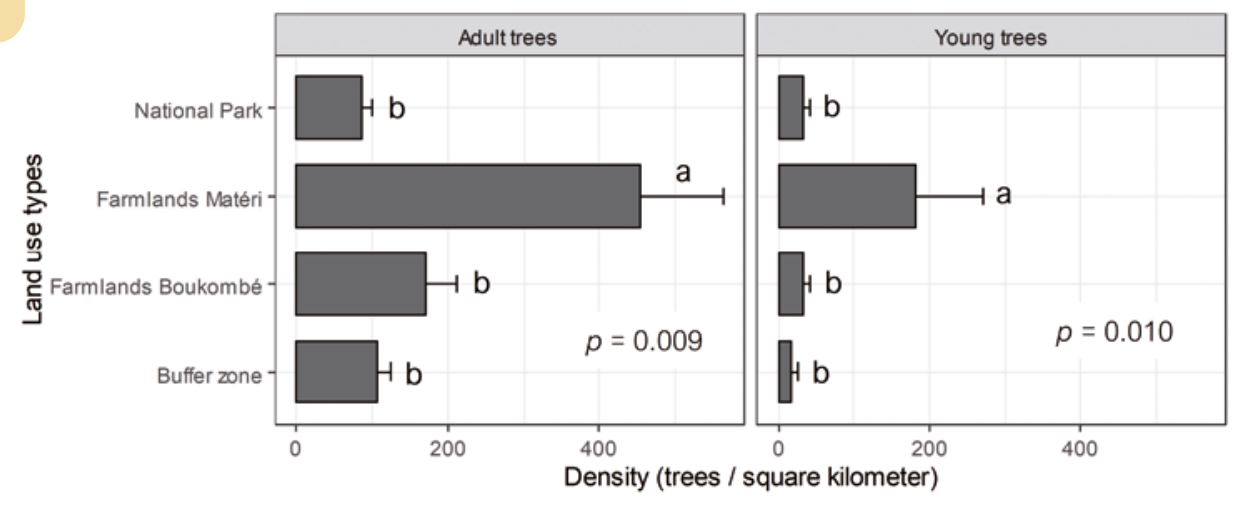

Figure 3.

Variation of density (mean \pm standard error) of Adansonia digitata tree across land use types. For the same stage (adult or young trees), mean with different letters denote significant differences $(p<0.05)$ among LUT after LSD test.

\section{Spatial structure of baobab tree in relationship to conspecific and other tree species LUT}

For each established plot, the distance, azimuth, and slope among trees were converted into $\mathrm{x}$ and $\mathrm{y}$ coordinates using Arpent 1.3.d. (Lejeune, 2001). The pair-correlation function was used to study the spatial pattern (SP) of trees (Benot et al., 2013). Baddeley et al. (2005) developed the global pair-correlation function $\mathrm{g}$ for a point process of two kinds of stimuli $i$ and $j$ (e.g. two different life stages i.e. adults and young) as follow:

$$
g_{i, j}(r)=\frac{K_{i, j}^{\prime}(r)}{2 \pi r}
$$

In this equation, $\mathrm{K}_{\mathrm{i}, \mathrm{j}}(\mathrm{r})$ is the derivative

Table II.

Variation of diameter and height (mean \pm standard error) of Adansonia digitata tree across land use types.

\begin{tabular}{|c|c|c|c|c|c|}
\hline \multirow[t]{2}{*}{ Study sites } & \multirow[b]{3}{*}{$\mathrm{m}$} & \multicolumn{2}{|c|}{ Diameter (cm) } & \multicolumn{2}{|c|}{ Total height (m) } \\
\hline & & Young & Adult & Young & Adult \\
\hline \multirow[t]{2}{*}{ National Park } & & $28.51^{\mathrm{a}}$ & $131.29^{a}$ & $7.55^{\mathrm{a}}$ & $14.46^{\mathrm{a}}$ \\
\hline & se & 14.40 & 7.98 & 3.69 & 0.41 \\
\hline \multirow[t]{2}{*}{ Buffer zone } & $\mathrm{m}$ & $17.66^{\mathrm{a}}$ & $188.52^{\mathrm{a}}$ & $1.89^{a}$ & $15.20^{\mathrm{a}}$ \\
\hline & se & 16.40 & 29.20 & 1.46 & 0.79 \\
\hline \multirow[t]{2}{*}{ Farmlands-Matéri } & $\mathrm{m}$ & $24.87^{\mathrm{a}}$ & $169.28^{\mathrm{a}}$ & $4.16^{a}$ & $13.56^{\mathrm{a}}$ \\
\hline & se & 5.64 & 25.40 & 1.14 & 0.94 \\
\hline \multirow[t]{2}{*}{ Farmlands-Boukombé } & $\mathrm{m}$ & $41.27^{\mathrm{a}}$ & $125.05^{\mathrm{a}}$ & $6.53^{a}$ & $15.32^{\mathrm{a}}$ \\
\hline & se & 4.72 & 7.98 & 0.39 & 0.36 \\
\hline$p$ & & 0.511 & 0.151 & 0.392 & 0.301 \\
\hline
\end{tabular}

Mean with different letters denote significant differences ( $p<0.05)$ among LUT, mean (m), standard error (se).
Table III.

Diameter size-class distribution slopes, permutation index and Simpson index of dominance for Adansonia digitata populations.

\begin{tabular}{|l|c|c|c|c|} 
Stand stability metrics & $\begin{array}{c}\text { National } \\
\text { Park }\end{array}$ & $\begin{array}{c}\text { Buffer } \\
\text { zone }\end{array}$ & $\begin{array}{c}\text { Farmlands- } \\
\text { Matéri }\end{array}$ & $\begin{array}{c}\text { Farmlands- } \\
\text { Boukombé }\end{array}$ \\
\hline SCD slope & -0.001 & -0.000 & -0.006 & -0.001 \\
\hline$p$ (slope significance) & 0.019 & 0.912 & 0.001 & 0.017 \\
\hline $\mathrm{R}^{2}(\%)$ & 62.86 & 82.59 & 87.83 & 64.41 \\
\hline Simpson Index (S) & 0.26 & 0.18 & 0.21 & 0.30 \\
\hline Permutation Index (P) & 3.02 & 6.42 & 1.77 & 4.38 \\
\hline
\end{tabular}

of Ripley's K function at distance $r$ (Ripley, 1991). This analysis is univariate when only one stimulus (i.e. $i=j$ ) is analysed and bivariate when the analyses concern two stimuli $(i \neq j)$. The function indicates whether the spatial relationship between two stimuli (e.g. adult versus young baobabs) is a spatial association, repulsion, or independence; and the spatial level $r$ at which these patterns occurred for bivariate analyses (Stoyan and Stoyan, 1994; Salako et al., 2019). When the analysis is univariate, the function indicates whether the spatial relationship is random, aggregated or regular. The significance of any observation pattern that deviates from the distribution predicted under the null model (complete spatial randomness for univariate SP or spatial independence for bivariate SP) was evaluated by comparing the observed distribution function to the confidence envelope generated by 500 Monte-Carlo simulations of the null model (Diggle et al., 2003). When $g(r)$ was for a given scale $r$ outside the simulation envelopes $(\neq 1)$, the null hypothesis of a complete random distribution (univariate) and independence (bivariate) was rejected at this scale. For a univariate point pattern, $g(r)=1$ shows a random distribution, and $g(r)>1$ and $g(r)<1$ indicate aggregative and regular spatial distribution, respectively. For a bivariate point pattern, $g_{i, j}(r)=1$ shows a spatial independence while $g_{i, j}(r)>1$, and $g_{i, j}(r)<1$ indicates a positive association (attraction) and a negative association (repulsion) respectively. Spatial analyses were produced in the package "Spatstat" (Diggle et al., 2003) of the statistical software R 3.0.3. 


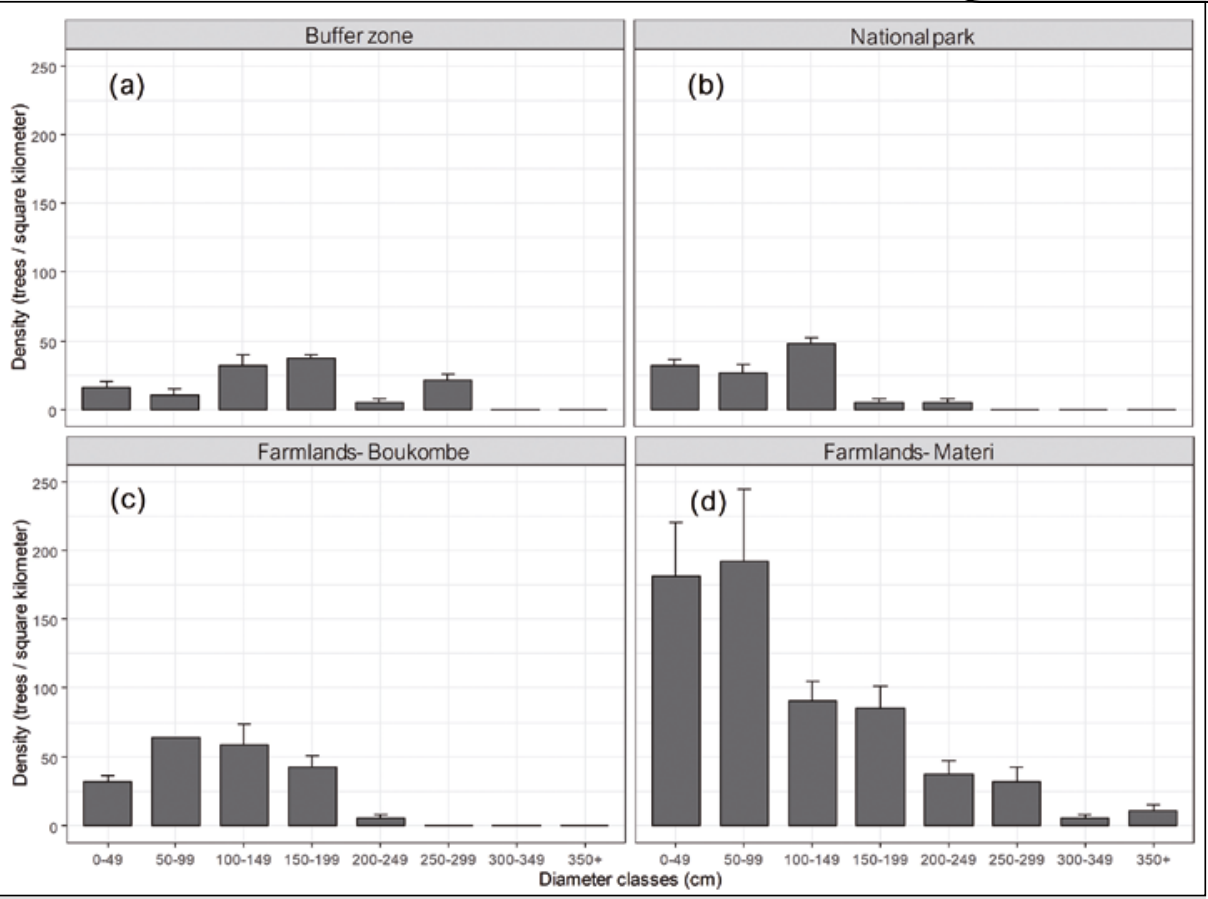

Figure 4.

Diameter size class distribution (mean \pm standard error) across land use types.

\section{Diameter and height size class distributions}

The diameter size-class distribution (figure 4) and the total height size class distribution (figure 5) differed markedly across LUT. In particular, results of the regression analyses for SCD curves showed that there were negative slopes in all LUT except in the buffer zone where the slope was statistically zero; i.e., there was no statistical variation of density in relationship to tree size class (table III, figure 4a). In the other land use types, the negative slopes indicate that there were lower individuals in large size-classes than in small size-classes (see figure $4 b$, $c$, and d). But, the low values of the slope $(-0.001,-0.006$ and -0.001 respectively in the National Park, farmlands-Matéri and farmlands-Boukombé) showed that the slope is relatively flat, indicating a low gradient slope, and hence lower recruitment in baobab population across

\section{Results}

\section{Demographic structure and stability across LUT}

\section{Population density and dendrometric characteristics across LUT}

The density of the baobab population significantly varied with the LUT both for young trees $(p \leq 0.05)$ and for adult trees ( $p \leq 0.05$ ) (figure 3 ). For both young and adult trees, densities were higher in farmlands-Matéri, followed by farmlands-Boukombé (approximatively six times lower for young trees and three times lower for adults) (figure 3). Compared to farmlands, baobab density in the buffer zone was approximatively eleven times lower for young trees and four times for adults. Similarly, baobab density in the national park was approximatively six times lower for young trees and five times for adults (figure 3), thus indicating lower regenerations and adult trees compared to farmlands. There were altogether fewer young trees than adult ones. Total height and $\mathrm{dbh}$ did not vary significantly among LUT ( $p>0.05$ ) either for young or adult trees (table II). the LUT, except in the farmlands of Matéri (figure 4d).

\section{Population stability across LUT}

The Simpson index of dominance (S) was above 0.1 for all LUT, indicating that the diameter size-classes of baobab populations in the LUT were not spread in a uniform way, particularly in the National Park and farmlands-Boukombé (table III). All values of the permutation index $(P)$ were greater than zero
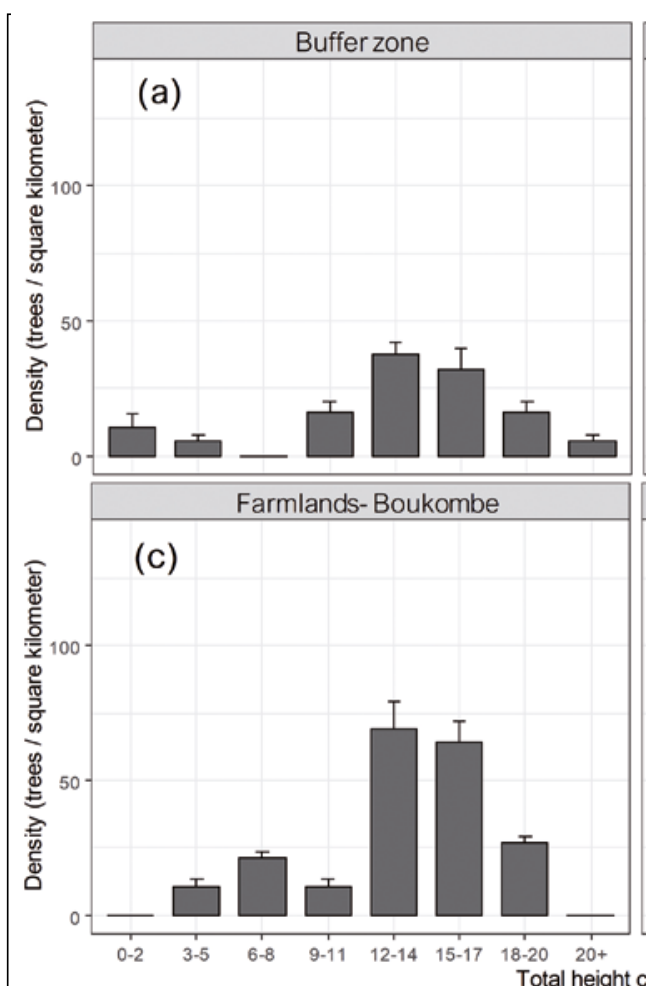

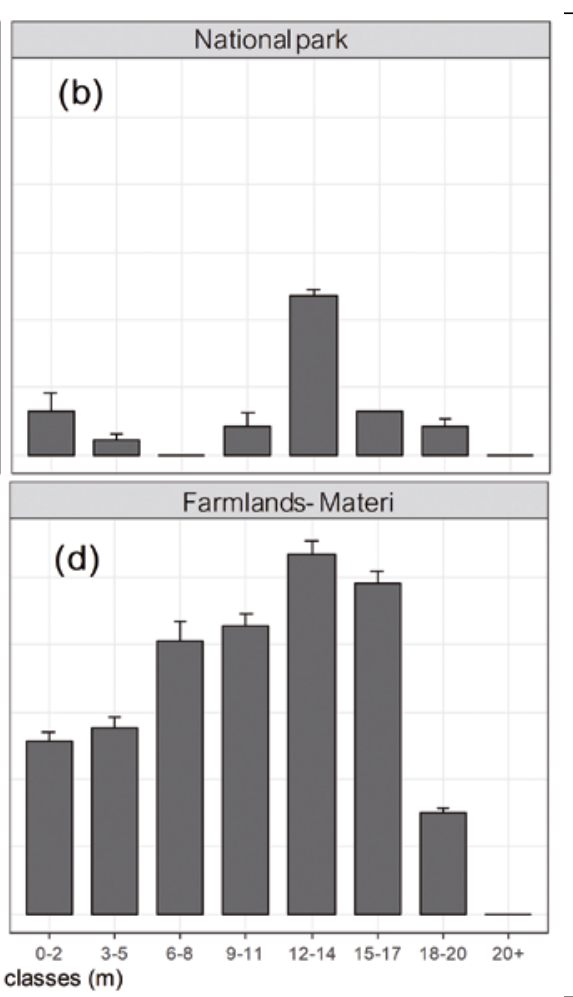

Figure 5.

Total height size class distribution (mean \pm standard error) across land use types. 
Table IV.

Univariate and bivariate intraspecific spatial pattern.

\begin{tabular}{|c|c|c|c|c|c|c|c|}
\hline \multirow[t]{2}{*}{ Land uses } & \multirow[t]{2}{*}{ Stages } & \multicolumn{3}{|c|}{ Adansonia digitata } & \multicolumn{3}{|c|}{ Other tree species } \\
\hline & & P1 & P2 & P3 & P1 & P2 & P3 \\
\hline \multirow[t]{4}{*}{$\begin{array}{l}\text { National } \\
\text { Park }\end{array}$} & Young & Random & - & Random & $\begin{array}{c}\text { Aggregative } \\
(2<r<10)\end{array}$ & $\begin{array}{c}\text { Aggregative } \\
(5<r<12)\end{array}$ & Random \\
\hline & Adult & Random & Random & Random & Random & Random & Random \\
\hline & Young - Adult & Independence & Independence & $\begin{array}{c}\text { Association } \\
(1<r<3)\end{array}$ & Independence & Independence & Independence \\
\hline & Adult -Young & Independence & Independence & $\begin{array}{c}\text { Association } \\
(1<r<3)\end{array}$ & Independence & Independence & Independence \\
\hline \multirow[t]{4}{*}{ Buffer zone } & Young & Random & - & - & Random & Random & Random \\
\hline & Adult & Random & Random & Random & Random & Random & Random \\
\hline & Young - Adult & $\begin{array}{c}\text { Association } \\
(3<r<8)\end{array}$ & Independence & - & Independence & Independence & Independence \\
\hline & Adult -Young & $\begin{array}{c}\text { Association } \\
(3<r<8)\end{array}$ & Independence & - & Independence & Independence & Independence \\
\hline \multirow{4}{*}{$\begin{array}{l}\text { Farmlands- } \\
\text { Matéri }\end{array}$} & Young & Random & Random & Random & Random & Random & - \\
\hline & Adult & Random & Random & $\begin{array}{c}\text { Aggregative } \\
(3<r<15)\end{array}$ & $\begin{array}{c}\text { Aggregative } \\
(1<r<3)\end{array}$ & $\begin{array}{c}\text { Aggregative } \\
(2<r<4)\end{array}$ & Random \\
\hline & Young - Adult & Independence & Independence & $\begin{array}{l}\text { Association } \\
(2<r<15)\end{array}$ & Independence & Independence & Independence \\
\hline & Adult -Young & Independence & Independence & $\begin{array}{c}\text { Association } \\
(2<r<15)\end{array}$ & Independence & Independence & Independence \\
\hline \multirow{3}{*}{$\begin{array}{l}\text { Farmlands- } \\
\text { Boukombé }\end{array}$} & Young & Random & Random & Random & - & - & Random \\
\hline & Adult & Random & Random & Random & Random & Random & Random \\
\hline & Young - Adult & Independence & Independence & Independence & Independence & Independence & Independence \\
\hline
\end{tabular}

$\mathrm{P} 1, \mathrm{P} 2, \mathrm{P} 3$ : plots, $r=$ radius in metre is the scale at which the spatial pattern was observed.

(table III), indicating that baobab has a discontinuous SCD in all LUT, particularly higher in the buffer zone $(P=6.42)$ and the farmlands-Boukombé $(P=4.38)$. Quotients calculated between consecutive size-classes were not also constant (figure 6). This indicates a certain level of instability in studied populations.

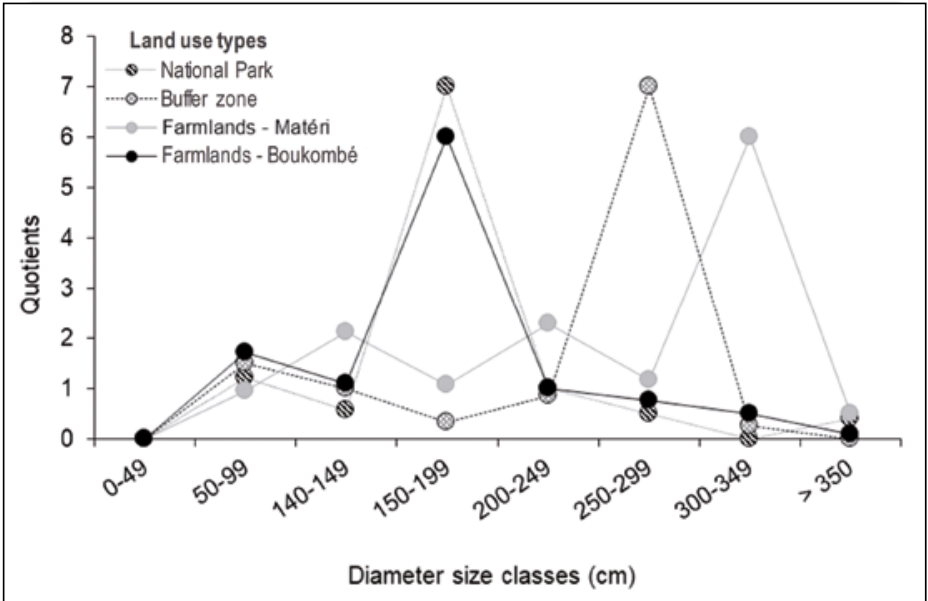

Figure 6.

Quotients between each successive size-class for baobab populations.

\section{Spatial structure of baobab in relationship to its conspecific and other tree species: variation across LUT}

\section{Univariate and bivariate intraspecific spatial relationship}

Figure 7 shows the maps of the baobab individuals and other tree species in the twelve plots. In total, 180 spatial patterns analyses were conducted. Because not all 180 corresponding graphical representations could be reported here, results are summarized in table IV and V and examples of graphical representations are displayed in figure 8 .

For the univariate analyses, both young and adult trees of baobab and other species had a random spatial distribution in all plots, irrespective of the LUT. By contrast, in the National Park and the farmlands of Matéri, young and adult trees of other species showed aggregative pattern within 1 to $12 \mathrm{~m}$ radius (table IV). For the bivariate analyses, results showed independence in the spatial distribution of young and adult baobab trees in at least two of the three plots 
per LUT. Some positive associations (attractions) within 1 to $15 \mathrm{~m}$ radius were found between young and adult baobab trees in both directions in one of the three plots in the National Park, the buffer zone, and the farmlands-Matéri (table IV). For the other species, the distribution of young trees was independent of adult trees and vice-versa in all plots, irrespective of the LUT (table IV).

\section{Bivariate interspecific spatial relationship}

The spatial distribution of young and adult baobab trees was independent of the distribution of other species irrespective of the stages (young or adult) and the LUT (table V). Similarly, the distribution of young and adult of other tree species was independent of the distribution of baobab trees irrespective of the stages (young or adult) and the LUT. But, loosely positive associations of other tree species with baobab trees were obtained in two plots.

\section{Discussion}

This study compared tree density, dendrometric characteristics, diameter and height size class distributions, and spatial structure of baobab among three land use types: national park, buffer zone, and farmlands (Matéri and Boukombé). The study showed that there was lower adult ( 3 to 5 times) and young (6 to 11 times) tree density in the national park than in farmlands, especially in Matéri where the highest densities were recorded. In addition, the diameter size-class distribution (SCD) differed markedly across LUT with farmlands in Matéri having the higher SCD slope (in absolute value). Furthermore, populations were relatively more stable in farmlands in Matéri than in other LUT including the national park. Additionally, both young and adult trees of baobab and other species had a random spatial distribution in most of the plots, irrespective of the LUT. Also, spatial distribution of adults and young trees of bao- bab was independent in either direction though some rare positive associations were observed except in farmlands in Boukombé, while young and adult trees of other species were overall independently distributed between each other. Lastly, the spatial distribution of baobab trees was independent of other species irrespective of the tree size (young or adult) except some rare positive associations either between young of baobab and other species or between adults. 
Table V.

Bivariate interspecific spatial pattern between baobab trees (young and adults) and other tree species (young and adults).

\begin{tabular}{|c|c|c|c|c|}
\hline Land use & Plots & $\begin{array}{c}\text { Pairs of } \\
\text { stages }(i-j)\end{array}$ & $\begin{array}{c}\text { Adansonia digitata - } \\
\text { Other trees } \\
\text { (baobab as focal species) }\end{array}$ & $\begin{array}{c}\text { Other trees - } \\
\text { Adansonia digitata } \\
\text { (other species as focal) }\end{array}$ \\
\hline \multirow{12}{*}{$\begin{array}{l}\text { Pendjari } \\
\text { National Park }\end{array}$} & \multirow[t]{4}{*}{$\mathrm{P} 1$} & Young - Young & Independence $(6<r<27)$ & Independence \\
\hline & & Young - Adult & Independence & Independence \\
\hline & & Adult - Young & Independence & Independence \\
\hline & & Adult - Adult & Independence & Independence \\
\hline & \multirow[t]{4}{*}{ P2 } & Young - Young & Independence & Independence \\
\hline & & Young - Adult & Independence & Independence \\
\hline & & Adult - Young & Independence & Independence \\
\hline & & Adult - Adult & Independence & Independence \\
\hline & \multirow[t]{4}{*}{ P3 } & Young - Young & Association $(15<r<17)$ & Independence \\
\hline & & Young - Adult & Independence & Independence \\
\hline & & Adult - Young & Independence & Independence \\
\hline & & Adult - Adult & Independence $(0<r<20)$ & Independence $(0<r<20)$ \\
\hline \multirow[t]{12}{*}{ Buffer zone } & \multirow[t]{4}{*}{ P1 } & Young - Young & Independence & Independence \\
\hline & & Young - Adult & Independence & Independence \\
\hline & & Adult - Young & Independence & Independence \\
\hline & & Adult - Adult & Independence & Independence \\
\hline & \multirow[t]{4}{*}{ P2 } & Young - Young & Independence & Independence \\
\hline & & Young - Adult & Independence & Independence \\
\hline & & Adult - Young & Independence & Independence \\
\hline & & Adult - Adult & Independence & Independence \\
\hline & \multirow[t]{4}{*}{ P3 } & Young - Young & - & Independence \\
\hline & & Young - Adult & - & - \\
\hline & & Adult - Young & Independence & - \\
\hline & & Adult - Adult & Association $(1<r<3)$ & Independence \\
\hline \multirow{12}{*}{$\begin{array}{l}\text { Farmlands- } \\
\text { Matéri }\end{array}$} & \multirow[t]{4}{*}{$\mathrm{P} 1$} & Young - Young & Independence & Independence \\
\hline & & Young - Adult & Independence & Independence \\
\hline & & Adult - Young & Independence $(0<r<7)$ & Independence \\
\hline & & Adult - Adult & Independence & Independence \\
\hline & \multirow[t]{4}{*}{ P2 } & Young - Young & Independence & Independence \\
\hline & & Young - Adult & Independence & Independence \\
\hline & & Adult - Young & Independence & Independence \\
\hline & & Adult - Adult & Independence $(2<r<3)$ & Independence $(2<r<3)$ \\
\hline & \multirow[t]{4}{*}{ P3 } & Young - Young & Independence & Independence \\
\hline & & Young - Adult & Independence & Independence \\
\hline & & Adult - Young & Independence & Independence \\
\hline & & Adult - Adult & Independence & Independence \\
\hline \multirow{12}{*}{$\begin{array}{l}\text { Farmlands- } \\
\text { Boukombé }\end{array}$} & \multirow[t]{4}{*}{ P1 } & Young - Young & Independence $(10<r<22)$ & Independence $(10<r<22)$ \\
\hline & & Young - Adult & Independence & Independence \\
\hline & & Adult - Young & Independence & Independence \\
\hline & & Adult - Adult & Independence & Independence \\
\hline & \multirow[t]{4}{*}{ P2 } & Young - Young & Independence & Independence \\
\hline & & Young - Adult & Independence & Independence \\
\hline & & Adult - Young & Independence & Independence \\
\hline & & Adult - Adult & Independence & Independence \\
\hline & \multirow[t]{4}{*}{ P3 } & Young - Young & Independence & Independence \\
\hline & & Young - Adult & Independence & Independence \\
\hline & & Adult - Young & Independence & Independence \\
\hline & & Adult - Adult & Independence & Independence \\
\hline
\end{tabular}

Impact of LUT on the demographic structure and stability of baobab stands

This study showed that the LUT has an impact on the demographic structure of baobab trees. The low baobab tree density that was observed in the national park can be partly attributed to several factors including the pressure exerted by the baboons on the baobab fruits and the trampling, feeding activities and damage to baobab trees by megaherbivores, particularly elephants. Baboons consume baobab fruits before maturity and then regurgitate or defecate them and deposit them in places at a distance far from the mother tree (Charles-Dominique, 1995) which may limit the process of seed development (Pochron, 2005). According to Venter and Witkowski (2011), the fruit production has been reduced by at least $85 \%$ in natural reserves. Kassa et al. (2014) have recently reported feeding activities and damage to baobab trees by elephants in the Pendjari National Park. The authors also highlight that the pressure on baobab trees in the park is increasing due to increasing elephant density from neighbouring reserves. However, Schumann et al. (2010) reported higher baobab tree density in W Park compared to communal lands in Burkina-Faso, a phenomenon also reported in South Africa (Edkins et al. 2008). These contrasting findings with our study may probably be partly attributed to differences in elephant population density between parks and local environmental conditions. Elephant density in W National Park is comparatively lower than that in the Pendjari National Park (Bouché et al., 2004). The higher tree density in the farmlands of Matéri is also consistent with findings of Duvall (2007) who reported a positive association between human settlement and baobab recruitment. The authors suggested that human settlement leads directly and indirectly to the development of baobab groves at settlement sites. Indeed, consumption of the fruit and the dispersion of the baobab seeds by humans, especially in farmlands and around homesteads could contribute to higher baobab tree density in farmlands. This is consistent with the architectural landscapes of the study area where farmlands and homestead are contiguous. However, the low tree density found in farmlands of Boukombé highlights that this trend might not be similar across geogra- 
phical locations, which might be attributed to environmental conditions and socio-cultural characteristics of people and their interactions with the species in a specific area. In the National Park, the highest density was found in the diameter class between 100 and $149 \mathrm{~cm}$, while in the farmlands and buffer zone was in the range of 0 and $49 \mathrm{~cm}$ suggesting that younger baobab trees were more common in the farmlands than in the National Park. This is most likely because of some recurrent perturbations to the trees including pruning for the leaves, which are highly consumed and pollarding that may have limited baobab tree growth. Similar findings were reported for baobab in Burkina-Faso (Schumann et al., 2010) and for the shea tree (Vitellaria paradoxa) in Benin (Djossa et al., 2008).

The baobab population structure as revealed by the SCD of diameter was not stable in any of the LUT. However, it is relatively better in farmlands in Matéri than in the National Park and other sites, suggesting that baobab population is healthier in farmlands in Matéri than in the National Park and other sites. Actually, the SCD slope was in the form of an inverse-J shaped, which characterizes species with abundant and constant regeneration and this was steeper in farmlands in Matéri than in other LUT. The observed differences in SCD are likely the consequence of factors already discussed above, affecting the species natural regeneration and adult tree density in the studied LUT. Schumann et al. (2010) observed contrastingly a better baobab SCD in W Park compared to communal land in Burkina-Faso, supporting the view that impact of LUT on important species is context-dependent. On the other hand, livestock in farmlands and wildlife in national parks can negatively affect baobab growth and ultimately its population structure and stability through trampling young plants and predation of unripe fruits. This situation may affect recruitment and the longterm population structure and stability (Venter and Witkowski, 2011, 2013). In northern Benin where this study was conducted, Assogbadjo et al. (2005) have also shown that, fires and trampling due to cattle grazing are the main source of pressure on wild baobab seedlings. In South Africa, up to $87 \%$ of sapling mortality is caused by domestic use and trampling (Venter and Witkowski, 2011,

Figure 8.
2013). According to Sinsin and Saidou (1998), fire is a management tool used every year in the Pendjari Biosphere Reserve for the development and renewal of resources for native herbivores such as antelopes. Yet, fire in the process is also reported to reduce trees' seedling survival in the savannah (Kassa et al., 2014). Furthermore, the stripping of bark of baobab trees by elephants contributed to the loss of mature Baobab species on a large scale (Barnes, 1980; Edkins et al., 2008). This bark stripping, which has also been reported to increasing in the Pendjari National Park (Kassa et al., 2014), might have contributed to the observed trend in baobab tree SCD. Therefore, the unstable population trend observed in landscapes dominated by human (farmlands) is probably linked to human activities while in the National Park it is probably due to recurrent fires and feeding activities of megaherbivores. Combined with fruits and seed predation by frugivorous, these factors could induce episodic regeneration, which may lead to the observed population structure. Djossa et al. (2008) reported similar findings on Vitellaria paradoxa in the study area, which the authors partly attributed to overharvesting of NTFPs and land degradation and this, may also apply to baobab. The overharvested products
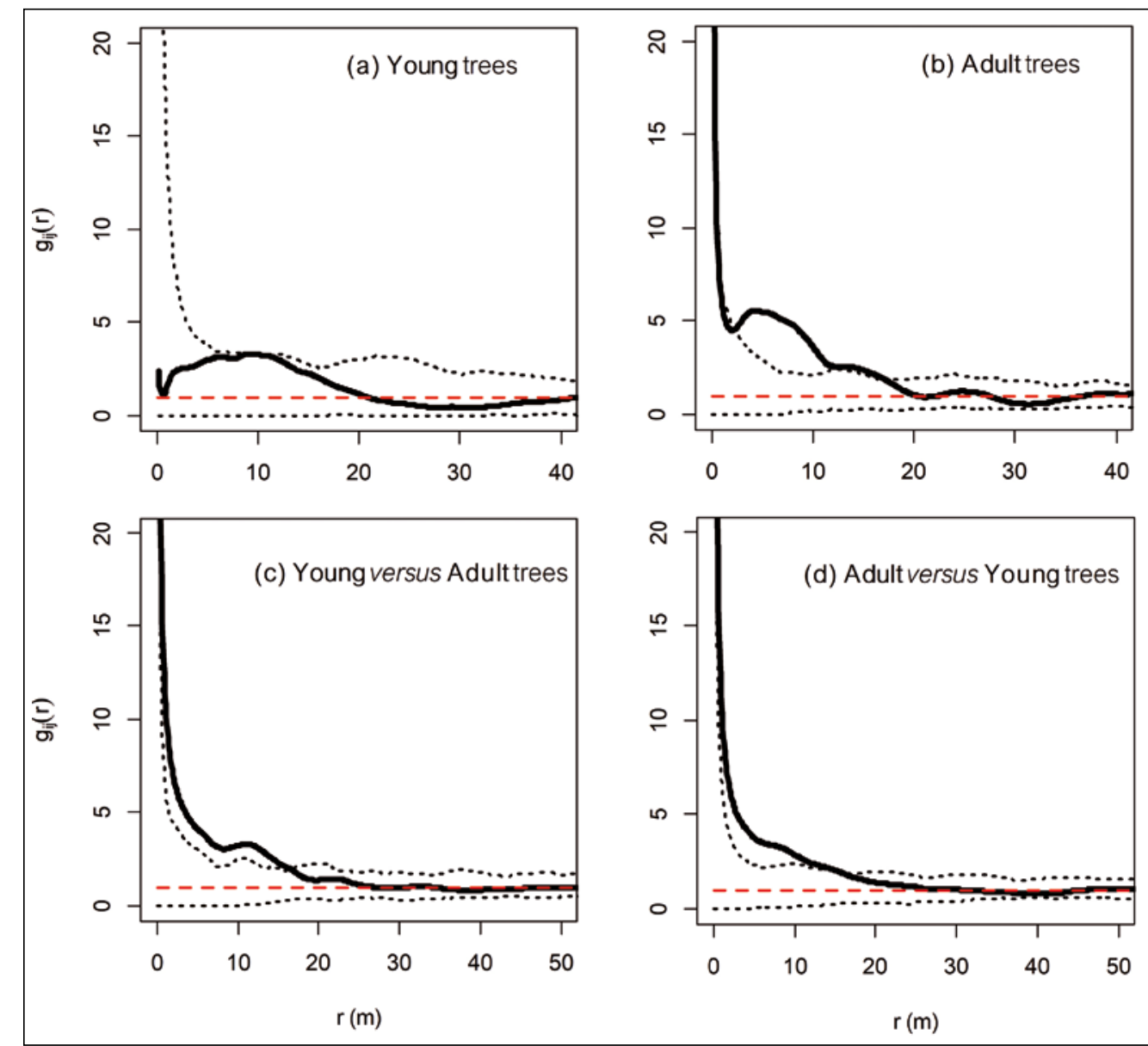

Graphs of the pair correlation function for univariate ( $a$ - young trees, $b$ - adult trees) and bivariate intraspecific ( $c$ - young trees versus adult trees, $d$ - adult trees versus young trees) spatial analyses for baobab trees in plot 3 of farmland sites in Matéri taken as example for illustration. Full bold lines show the statistic calculated from data. The horizontal red dashed line shows the pair correlation function expected from a completely random / independent Poisson process. Dotted lines are approximate $95 \%$ confidence envelopes for the null hypothesis (random/ independent spatial pattern), obtained from the 500 independent simulations. 
for baobab are namely the fruits from which pulp and seeds are collected and leaves. These products are gaining more interest on local, regional and international market and consequently exerting pressure on natural populations. Intense research on the species domestication is essential to ensure that the species is effectively integrated in agricultural systems. Altogether, farmlands particularly in Matéri, seem to offer better habitat for the conservation of baobab and particularly because of its usefulness.

\section{Impact of LUT on the intraspecific and interspecific spatial structure of baobab trees}

Findings suggest that both young and adult baobab trees have a random distribution, irrespective of the LUT. In the National Park, this random distribution can be partly explained by the zoochorous dispersal induced by baboons and elephants that roam in these environments. Baboons and elephants are consistently reported to feed on baobab in the Pendjari National Park (Kassa et al., 2014). Baboons consume baobab fruits even before maturity while elephants, which are documented as effective long-distance dispersers for many fruit species (Blake et al., 2009; Beaune et al., 2013) consume ripe fruit. Zoochory can indeed promote random distribution when performed by animals in their movements (Abdourhamane et al., 2017). It has also been reported that baobab trees are highly debarked by elephants in the National Park, and this may increase tree mortality and favor random spatial distribution of surviving individuals (Kassa et al., 2014). Salako et al. (2016) reported similar observations on palm trees (Borassus aethiopum) in this Park. In addition, historical fire management regimes in this savannah ecosystem can contribute to the random distribution of the species in the national park and the buffer zone where fires are often used as a management tool either for tourism or to control of grass. Svatek et al. (2018) has actually reported that in continuous fire regime, small to large adult trees tended to exhibit random distribution. Tree aggregation was shown to rather correlate with the strength of dispersal limitation, which is unlikely for baobab trees in the PNP given the diverse dispersers in the environment (Seidler and Plotkin, 2006). The random and loosely aggregated distributions in farmlands could have been favored by agricultural activities like land clearing, livestock, and exploitation of fruits and leaves (Assogbadjo et al., 2005; Chirwa et al., 2006). Dispersion of the baobab seeds by humans, especially in farmlands and around homestead, could partially also explain the random distribution patterns observed in farmlands as previously reported for the shea butter tree in the region (Djossa et al., 2008). Nevertheless, the aggregative pattern observed in farmlands of Matéri could reflect the higher localized density of baobab that might be attributed to human activities. Actually, Duvall (2007) reported that human settlement leads directly and indirectly to the development of baobab groves at settlement sites. Our findings, regarding the random and aggregative distribution of trees of other species in different LUT are in agreement with earlier reports which indicate that tree species in the tropical ecosystems show aggregation or random distribution depending on their dispersal trajectory, environment heterogeneity, etc. (Condit et al., 2000). As regards the bivariate spatial relationship, results reveal independence between baobab adult and juvenile individuals and between baobab and other tree species in all LUT. This independence in human-dominated landscapes is probably due to actions such as agricultural practices and the non-random destruction of big trees for farming. However, in the national park, this independence between trees could be linked to grazing and trampling of young trees by animals but also that tree species co-occurring with baobab are wind dispersed. The loosely positive association observed between baobab and individual of other tree species and between adult baobabs and juvenile baobabs, on the other hand, suggests a good tolerance between these species.

\section{Conclusion}

This study showed that baobab tree density either young or adult, is higher in farmlands with a better size class distribution and population stability, hence better conserved than in the strictly protected area (Pendjari National Park). However, observed differences between the two farmlands sites (Matéri and Boukombé) suggest that difference between the park and farmlands is not applicable to all farmlands and may be context dependent, probably linked to local environmental conditions, socio-ecological context, and interactions with baobab. Despite the low density of young baobab trees in all land use types and the LUT induced impact on its variation, baobab trees are still well conserved because of their longevity and extremely low adult mortality rates. Baobab trees have random distribution in most habitats. In the National Park, this is partially attributed to dispersal by elephants and baboons but also to elephant feeding activities on baobab. In farmlands, this is attributed to anthropogenic activities. We conclude that there is a need for active conservation of baobab in the Pendjari National Park. However, in farmlands, baobab conservation status can be improved by promoting the species by building capacity of the farmers in propagating baobab and value addition of baobab-derived products.

\section{Acknowledgments}

The authors thank the Intra-ACP academic mobility scheme to Train Crop Scientists for Africa Agriculture for the financial support to Orgely Doris I. Assogba. Additional supports were obtained from Agropolis foundation, Cariplo foundation, and Daniel \& Nina Carasso foundation via the TREEFOOD project; and the MasterCard Foundation via the Regional Universities Forum for Capacity Building in Agriculture BAO-CHAIN project (RU/2018/CARP+/01). The authors are very grateful to the local people for their assistance during the fieldwork. 


\section{References}

Abdourhamane H., Rabiou H., Diouf A., Morou B., Mahamane A., Bellefontaine R., 2017. Structure démographique et répartition spatiale des populations de Sclerocarya birrea (A. Rich.) Hochst. du secteur sahélien du Niger. Bois et Forêts des Tropiques, 333: 55-66. https://revues.cirad.fr/index.php/BFT/article/view/ID-BFT-161121

Adomou A., Sinsin B., Akoégninou A., Maesen J., 2010. Plant species and ecosystems with high conservation priority in Benin. In: van der Burgt X., van der Maesen J., Onana J.-M. (eds). Systematics and Conservation of African Plants. Proceedings of the 18th AETFAT Congress, Yaounde, Cameroon. London, United Kingdom, Kew Publishing, 429-444.

Assogbadjo A. E., Sinsin B., Codjia J. T. C., Van Damme P., 2005. Ecological diversity and pulp, seed and kernel production of the baobab (Adansonia digitata) in Benin. Belgian Journal of Botany, 138: 47-56.

Baddeley A., Turner R., Møller J., Hazelton M., 2005. Residual analysis for spatial point processes (with discussion). Journal of the Royal Statistical Society, 67 (5): 617-666. https://doi.org/10.1111/ j.1467-9868.2005.00519.x

Barnes R., 1980. The decline of the baobab tree in Ruaha National Park, Tanzania. African Journal of Ecology, 18 (4): 243-252. https:// doi.org/10.1111/j.1365-2028.1980.tb01053.x

Beaune D., Fruth B., Bollache L., Hohmann G., Bretagnolle F., 2013. Doom of the elephant-dependent trees in a Congo tropical forest. Forest Ecology and Management 295: 109-117.

Benot M. L., Bittebiere A. K., Ernoult A., Clement B., Mony C., 2013. Fine-scale spatial patterns in grassland communities depend on species clonal dispersal ability and interactions with neighbours. Journal of Ecology, 101: 626-636. https://doi.org/10.1111/1365$\underline{2745.12066}$

Blake S., Deem S. L., Mossimbo E., Maisels F., Walsh P., 2009. Forest Elephants: Tree Planters of the Congo. Biotropica, 41: 459-468.

Botha J., Witkowski E., Shackleton C., 2002. A comparison of anthropogenic and elephant disturbance on Acacia xanthophloea (fever tree) populations in the Lowveld, South Africa. Koedoe, 45: 9-18. https://doi.org/10.4102/koedoe.v45i1.10

Bouché P., Lungren C., Hien B., Omondi P., 2004. Recensement aérien total de l'Écosystème "W"-Arly-Pendjari-Oti-Mandouri-Keran (WAPOK). CITES-MIKE, ECOPAS, PAUCOF, Bénin, Burkina Faso, Niger, Togo, $115 \mathrm{p}$.

Charles-Dominique P., 1995. Interactions plantes-animaux frugivores, conséquences sur la dissémination des graines et la régénération forestière. Revue d'Écologie, 50 : 223-235. http://hdl. handle.net/2042/54805

Chirwa M., Chithila V., Kayambazinthu D., 2006. Distribution and Population Structures of Adansonia digitata in Some Parts of Ntcheu, Dedza and Mangochi Districts, Malawi. Goverment of the Republic of Malawi, FRIM Report 6002, 32 p.

Condit R., Ashton P. S., Baker P., Bunyavejchewin S., Gunatilleke S., Gunatilleke N., et al., 2000. Spatial patterns in the distribution of tropical tree species. Science, 288 (5470): 1414-1418. https://doi. org/10.1126/science.288.5470.1414

Dhillion S. S., Gustad G., 2004. Local management practices influence the viability of the baobab (Adansonia digitata Linn.) in different land use types, Cinzana, Mali. Agriculture, Ecosystems \& Environment, 101 (1): 85-103.
Diggle P. J., Ribeiro P. J., Christensen O. F., 2003. An introduction to model-based geostatistics. In: Møller J. (ed.). Spatial Statistics and Computational Methods. New York, USA, Springer, 43-86. https:// doi.org/10.1007/978-0-387-21811-3_2

Djossa B. A., Fahr J., Wiegand T., Ayihouénou B., Kalko E., Sinsin B., 2008. Land use impact on Vitellaria paradoxa C.F. Gaerten. stand structure and distribution patterns: a comparison of Biosphere Reserve of Pendjari in Atacora district in Benin. Agroforestry Systems, 72 (3): 205-220. https://doi.org/10.1007/s10457-0079097-y

Duvall C. S., 2007. Human settlement and baobab distribution in south-western Mali. Journal of Biogeography, 34 (11): 1947-1961.

Edkins M., Kruger L., Harris K., Midgley J., 2008. Baobabs and elephants in Kruger National Park: nowhere to hide. African Journal of Ecology, 46: 119-125. https://doi.org/10.1111/i.13652028.2007.00798.x

Gnanglè C. P., Glèlè Kakaï R., Assogbadjo A. E., Vodounnon S., Afouda Yabi J., Sokpon N., 2011. Tendances climatiques passées, modélisation, perceptions et adaptations locales au Bénin. Climatologie, 8: 27-40. http://lodel.irevues.inist.fr/climatologie/ index.php?id $=259$

Gruenwald J., Galizia M., 2005. Market Brief in the European Union for selected natural ingredients derived from native species: Adansonia digitata L. Baobab. United Nations Conference on Trade and Development (UNCTAD) BioTrade Initiative/BioTrade Facilitation Programme (BTFP) UNCTAD/DITC/TED, Geneva, 35 p. http://www. biotrade.org/ResourcesPublications/biotradebrief-baobab.pdf

Helm C. V., Witkowski E., 2012. Characterising wide spatial variation in population size structure of a keystone African savanna tree. Forest Ecology and Management, 263: 175-188. https://doi. org/10.1016/j.foreco.2011.09.024

Houéhanou T. D., Assogbadjo A. E., Glèlè Kakaï R., Kyndt T., Houinato M., Sinsin B., 2013. How far a protected area contributes to conserve habitat species composition and population structure of endangered African tree species (Benin, West Africa). Ecological Complexity, 13: 60-68. https://doi.org/10.1016/i.ecocom.2013.01.002

Kassa B. D., Fandohan B., Azihou A. F., Assogbadjo A. E., Oduor A. M., Kidjo F. C., et al., 2014, Survey of Loxodonta africana (Elephantidae)caused bark injury on Adansonia digitata (Malavaceae) within Pendjari Biosphere Reserve, Benin. African Journal of Ecology, 52: 385-394. https://doi.org/10.1111/aje.12131

Law R., Illian J., Burslem D. F., Gratzer G., Gunatilleke C., Gunatilleke I., 2009. Ecological information from spatial patterns of plants: insights from point process theory. Journal of Ecology, 97 (4): 616628. https://doi.org/10.1111/j.1365-2745.2009.01510.x

Lejeune P., 2001. Arpent 2.0, logiciel de saisie de données d'arpentage - Guide d'utilisation [Arpent 2.0, surveying data aquisition software]. FUSAGx. Note Technique Forestière, 5 : 1-12.

Lykke A. M., 1998. Assessment of species composition change in savanna vegetation by means of woody plants' size class distributions and local information. Biodiversity and Conservation, 7 (10): 1261-1275. https://doi.org/10.1023/A:1008877819286

Martins A. R., Shackleton C. M., 2017. Abundance, population structure and harvesting selection of two palm species (Hyphaene coriacea and Phoenix reclinata) in Zitundo area, southern Mozambique. Forest Ecology and Management, 398: 64-74. https://doi.org/10.1016/i.foreco.2017.05.005

McNeely J. A., 1997. Conservation and the Future: Trends and Options Toward the Year 2025. Gland, Belgium, International Union for Conservation of Nature, Biodiversity Policy Coordination Division, $119 \mathrm{p}$. 
Munthali C., Chirwa P. W., Changadeya W., Akinnifesi F. K., 2013. Genetic differentiation and diversity of Adansonia digitata L. (baobab) in Malawi using microsatellite markers. Agroforestry Systems, 87: 117-130. https://doi.org/10.1007/s10457-0129528-2

Obiri J., Lawes M., Mukolwe M., 2002. The dynamics and sustainable use of high-value tree species of the coastal Pondoland forests of the Eastern Cape Province, South Africa. Forest Ecology and Management, 166: 131-148. https://doi.org/10.1016/S03781127(01)00665-X

Philip M. S., 1994. Measuring Trees and Forests. 2nd ed. Wallingford, United Kingdom, CABI Publishing, 310 p.

Pochron S. T., 2005. Does relative economic value of food elicit purposeful encounter in the yellow baboons (Papio hamadryas cynocephalus) of Ruaha National Park, Tanzania? Primates, 46: 71-74. https://doi.org/10.1007/s10329-004-0104-x

Ripley B. D., 1991. Statistical Inference for Spatial Processes. Cambridge, United Kingdom, Cambridge University Press, 148 p.

Salako V. K., Azihou A. F., Assogbadjo A. E., Houéhanou T. D., Kassa B. D., Glèlè Kakaï R. L., 2016. Elephant-induced damage drives spatial isolation of the dioecious palm Borassus aethiopum Mart. (Arecaceae) in the Pendjari National Park, Benin. African Journal of Ecology 54: 9-19. https://doi.org/10.1111/aje.12253

Salako V. K., Kénou C., Dainou K., Assogbadjo A. E., Glèlè Kakaï R., 2019. Impacts of land use types on spatial patterns and neighbourhood distance of the agroforestry palm Borassus aethiopum Mart. in two climatic regions in Benin, West Africa. Agroforestry Systems, 93: 1057-1071. https://doi.org/10.1007/ s10457-018-0205-y

Schumann K., Wittig R., Thiombiano A., Becker U., Hahn K., 2010. Impact of land-use type and bark-and leaf-harvesting on population structure and fruit production of the baobab tree (Adansonia digitata L.) in a semi-arid savanna, West Africa. Forest Ecology and Management, 260: 2035-2044. https://doi.org/10.1016/j. forec0.2010.09.009

Seidler T. G., Plotkin J. B., 2006. Seed dispersal and spatial pattern in tropical trees. PLoS Biology, 4: 2132-2137. https://doi. org/10.1371/journal.pbio.0040344

Shen Y., Santiago L. S., Ma L., Lin G.-J., Lian J.-Y., Cao H.-L., etal., 2013. Forest dynamics of a subtropical monsoon forest in Dinghushan, China: recruitment, mortality and the pace of community change. Journal of Tropical Ecology, 29: 131-145. https://doi.org/10.1017/ S0266467413000059

Sidibe M., Williams J., 2002. Baobab. Adansonia digitata. Southampton, United Kingdom, International Centre for Underutilised Crops, 99 p.

Sinsin B., Saidou A., 1998. Impact des feux contrôlés sur la productivité des pâturages naturels des savanes soudanoguinéennes du ranch de l'Okpara au Bénin. Annales des Sciences Agronomiques, 1 (1): 11-30.

Stoyan D., Stoyan H., 1994. Fractals, Random Shapes, and Point Fields: Methods of Geometrical Statistics. Chichester, United Kingdom, John Wiley \& Sons, 389 p.

Svatek M., Rejžek M., Kvasnica J., Řepka R., Matula R., 2018. Frequent fires control tree spatial pattern, mortality and regeneration in Argentine open woodlands. Forest Ecology and Management, 408: 129-136.

Vellak A., Tuvi E. L., Reier Ü., Kalamees R., Roosaluste E., Zobel M., Pärtel M., 2009. Past and present effectiveness of protected areas for conservation of naturally and anthropogenically rare plant species. Conservation Biology, 23: 750-757. https://doi. org/10.1111/j.1523-1739.2008.01127.x
Venter S. M., Witkowski E. T., 2011. Baobab (Adansonia digitata L.) fruit production in communal and conservation land-use types in Southern Africa. Forest Ecology and Management, 261: 630-639. https://doi.org/10.1016/j.foreco.2010.11.017

Venter S. M., Witkowski E. T., 2013. Using a deterministic population model to evaluate population stability and the effects of fruit harvesting and livestock on baobab (Adansonia digitata L.) populations in five land-use types. Forest Ecology and Management, 303: 113-120. https://doi.org/10.1016/j.foreco.2013.04.013

Wiegand K., Ward D., Thulke H.-H., Jeltsch F., 2000. From snapshot information to long-term population dynamics of Acacias by a simulation model. Plant Ecology, 150: 97-114. https://doi. org/10.1023/A:1026574303048

Assogba et al. - Author's contributions

CONTRIBUTOR ROLE

CONTRIBUTOR NAMES

Conceptualization

O. D. I. Assogba, K. V. Salako, A. E. Assogbadjo, P. W. Chirwa

Data Curation

O. D. I. Assogba, K. V. Salako, B. Fantodji

Formal Analysis

O. D. I. Assogba, K. V. Salako,

B. Fantodji

Funding Acquisition

K. V. Salako, A. E. Assogbadjo, P. W. Chirwa

Investigation

O. D. I. Assogba, K. V. Salako, A. E. Assogbadjo

Methodology

O. D. I. Assogba, K. V. Salako, B. Fantodji, E. P. S. Assédé,

A. E. Assogbadjo, P. W. Chirwa

Project Administration A. E. Assogbadjo, P. W. Chirwa

Software

K. V. Salako

Supervision

A. E. Assogbadjo, P. W. Chirwa

Validation

O. D. I. Assogba, K. V. Salako, B. Fantodji, E. P. S. Assédé

Visualization O. D. I. Assogba, K. V. Salako, B. Fantodji, E. P. S. Assédé

Writing - Original O.D. I. Assogba,

Draft Preparation K. V. Salako

Writing - Review O. D. I. Assogba,

$\begin{array}{ll}\text { \& Editing } & \text { K. V. Salako }\end{array}$

Bois et Forêts des Tropiques - Revue scientifique du Cirad

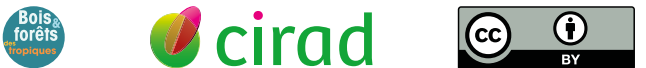

Cirad - Campus international de Baillarguet, 34398 Montpellier Cedex 5, France - Contact : bft@cirad.fr - ISSN : L-0006-579X 